\title{
Laktoperoksidaz Sistemine Karşı Sesamolün İnhibisyon Kinetiği
}

\author{
Inhibition Kinetics of Sesamol Against Lactoperoxidase System
}

\section{Ramazan KALIN ${ }^{1}$}

\section{ÖZ}

Antioksidan sistemleri gibi biyoaktif bileşenlerce zengin olan süt, sağlıklı bir beslenmenin vazgeçilmez ürünlerinden bir tanesidir. Süt, zararlı mikroorganizmalara karşı doğal bir savunma sistemine sahiptir. $\mathrm{Bu}$ sistem, özellikle bebeklerin büyüme ve gelişme dönemleri için çok önemlidir. Oksidoredüktaz enzim sinıfinda olan laktoperoksidaz (LPO; EC 1.11.1.7), doğada yaygın olarak insanlarda ve hayvanlarda bulunan peroksidaz ailesinin bir üyesidir. Susam tohumlarından elde edilen bir bileşik olan sesamol, çeşitli hastalık ve bozuklukların tedavisi için bilim camiası tarafından geniş çapta çalışılmış bir moleküldür. $\mathrm{Bu}$ çalışmada, sığır laktoperoksidaz sistemi üzerine sesamolün in vitro inhibisyon parametreleri belirlenmiştir. LPO enzimi, ligant olarak sülfanilamitin kullanıldığ 1 bir afinite kromatografisi tekniği ile tek kademede \%75,99 verim ile 467,51 kat saflaştırıldı. Sesamol LPO enzimini nM'lar seviyede güçlü bir şekilde inhibe ettiği belirlendi. Sesamol için $\mathrm{IC}_{50}$ ve $\mathrm{K}_{\mathrm{i}}$ değerleri sirasiyla 138,629 ve 80,599 $\pm 3,669$ olarak hesapland1. Aynı zamanda sesamol LPO üzerine yarışmalı bir inhibisyon etkisi gösterdi.

Anahtar Kelimeler: Afinite Kromatografisi, In vitro, Laktoperoksidaz, Sesamol.

\begin{abstract}
Rich in bioactive components such as antioxidant systems, milk is one of the indispensable products of a healthy diet. It has a natural defense system against harmful micro-organisms. This system is especially important for the growth and development periods of babies. Lactoperoxidase (LPO; EC 1.11.1.7), which is in the oxidoreductase enzyme class, is a member of the peroxidase family commonly found in humans and animals. Sesamol, a compound derived from sesame seeds, is a molecule widely studied by the scientists for the treatment of various diseases and disorders. In this study, in vitro inhibition parameters of sesamol on bovine lactoperoxidase system were determined. The LPO enzyme was purified 467.51 fold with a yield of $75.99 \%$ in one step with an affinity chromatography technique using sulfanilamide as ligand. It was determined that sesamol inhibits LPO enzyme strongly at $\mathrm{nM}$ level. $\mathrm{IC}_{50}$ and $\mathrm{K}_{\mathrm{i}}$ values for Sesamol were calculated as 138.629 and $80.599 \pm 3.669$, respectively. Also, sesamol showed a competitive inhibition effect on LPO.
\end{abstract}

Keywords: Affinity Chromatography, In vitro, Lactoperoxidase, Sesamol.

${ }^{1}$ Dr. Öğr. Üyesi, Ramazan KALIN, Erzurum Teknik Üniversitesi, Fen Fakültesi, Temel Bilimler Bölümü, ramazan.kalin@erzurum.edu.tr, ORCID 0000-0002-5917-1299 


\section{GÍRIS}

Sağlıklı bir yaşamda beslenme çok önemli bir yer tutmaktadır. Yaşam boyunca sağlıklı bir diyetle beslenilmesi büyüme ve gelişme için gerekli olan metabolik ürünlerin sağlanması açısından hayati görev üstlenmektedir. ${ }^{1} \quad$ Aynı zamanda sağlıklı beslenmenin bulaşıcı olmayan hastalıklar riskini azaltmada ve sağlığın geliştirilmesinde giderek daha fazla anahtar rol oynadığı kabul edilmektedir. Geçmiş 5000 yıla bakıldığı zaman, birçok insan popülasyonu diyetlerinde geviş getiren hayvanların (inek, keçi, koyun ve manda) sütünü sağlıklı beslenmenin bir parçası olarak kullanmışlardır. ${ }^{2} \mathrm{Bu}$ hayvanlardan elde edilen sütün (özellikle çiğ süt) sağlıklı beslenmede bu kadar çok tercih edilmesi, kendine özgü endojen mikrobiyal topluluğa sahip olduğu bilgisinden gelmektedir. Özellikle yeni doğan bebeklerde anne sütü, bebeğin sağlıklı bir yaşam sürdürmesi adına yararlı olan birçok biyoaktif moleküller sağladığından, doğumdan sonraki ilk dönemlerinde büyüme ve gelişme için ideal beslenme şeklidir. ${ }^{3}$

Oksidoredüktaz enzim sınıfının bir üyesi olan ve günümüzde birçok alanda kullanım potansiyeline sahip enzimler arasında yer alan peroksidazlar

(POD:E.C.1.11.1.7); prokaryotik, ökaryotik ve fotosentetik hücrelerde çok yaygın olarak bulunan enzimlerden bir tanesidir. ${ }^{4} \mathrm{Bu}$ enzimler; bakteri, maya, özellikle turp türleri gibi yüksek bitkiler, mantar ve sütü de kapsayan birçok kaynakta bulunur. Peroksidazlar, substrat afinitesi, inhibitörlere duyarlılık spesifik aktivite ve optimum $\mathrm{pH}$ gibi farklı biyokimyasal özelliklere sahip birçok izoenzime sahiptirler. ${ }^{5}$ Biyolojik sistemlerde metabolizma sırasında oluşan ve oksitleyici özelliğe sahip $\mathrm{H}_{2} \mathrm{O}_{2}$ 'nin zaman kaybetmeden ortamdan uzaklaştırılması gerekmektedir. Bu önemli görev, hücrelerde antioksidan enzimler olan katalaz ve substrat olarak çeşitli aromatik bileşikleri kullanan peroksidaz enzimleri tarafından gerçekleştirilir. ${ }^{6}$

Memeli POD enzimleri; sütte, gözyaşı damlasında ve tükürükte laktoperoksidaz enzimi, lökositler, trombositler, karaciğer ve dalakta glutatyon peroksidaz enzimi, uterus, akciğer duvarları, sitoplazma ve mitokondrilerde ise miyeloperoksidaz enzimi olarak lokalize durumdadırlar. ${ }^{7}$

Laktoperoksidaz enzimi (LPO: $\mathrm{H}_{2} \mathrm{O}_{2}-$ Oksidoredüktaz E.C. 1.11.1.7) memelilerin süt, gözyaşı, tükürük ve hava yolu yüzey sıvisında bulunur. Enzim, $78 \mathrm{kDa}$ molekül kütlesine sahip heme grubu içeren bir glikoproteindir. ${ }^{8}$ Laktoperoksidaz proteinle birlikte $\% 0.07 \quad \mathrm{Fe}^{+2}$ içermesi nedeniyle, metaloprotein grubuna dahil edilir. Enzim yapısinda bulunan bu demir atomu, enzimin katalitik merkezinde heme grubunun bir parçasını oluşturur. ${ }^{9}$ LPO'daki heme grubu, enzime disülfid köprüleriyle sıkıca bağlanan protoporfirin IX'dan oluşur. Süt içerisine doğal olarak salgılanan LPO, yeni doğan bebeklerin sindirim sistemindeki savunma mekanizması ile ilişkili olarak patojenik mikroorganizmalara karşı önemli bir rol oynayan enzimdir. ${ }^{10}$

Protein ve yağ içeriği çok yüksek olan susam (Sesamum indicum L.), yă̆ endüstrisinde kullanılan en önemli tohumlardan biridir. $^{11}$ Çalışmamızda kullanılan susam yağının bir bileşeni olan sesamol (3,4-metilendioksifenol) doğal bir organik bileşiktir. Sesamol, fenol türevi beyaz kristalli bir katıdır. ${ }^{12}$ Suda az çözünür, ancak çoğu yağ ile karışabilir. $\mathrm{Bu}$ bileşik heliotrope'nden organik sentez ile üretilebilir. Sesamol, yağların bozulmasını önleyebilecek bir antioksidan ve antifungal olarak bulunmuştur. ${ }^{13}$

Sunulan bu çalışmada, susam yağının bir bileşeni olan sesamol molekülünün in vitro koşullarda laktoperoksidaz sistemi üzerine inhibisyon etkileri araştırılmıştır. $\mathrm{Bu}$ amaç doğrultusunda öncelikle LPO enzimi sığır sütünden afinite kromatografisi tekniği kullanılarak saflaştırılmıştır. Daha sonra yapılan inhibisyon çalışmaları ile sesamol için $\mathrm{IC}_{50}$ ve $\mathrm{K}_{\mathrm{i}}$ değeri ile birlikte inhibisyon tipi belirlenmiştir. 


\section{MATERYAL VE METOT}

\section{Kimyasallar}

Sığır sütü Erzurum ilindeki yerel mandıralardan satın alınarak LPO enzimi bu sütten saflaştırıldı. Afinite kolonu ve saflaştırma için kullanılan kimyasallar, Amberlit CG-50- $\mathrm{NH}_{4}{ }^{+}$reçinesi, ABTS $\left(2,2^{\prime}-\right.$ Azino-bis(3-etilbenztiyoazolin-6-sülfonik asit)), L-tirozin, $\mathrm{CNBr}$-aktifleştirilmiş sefaroz 4B, sülfanilamit, sığır serum albümin (BSA), hidrojen peroksit, sesamol ve elektroforez için kullanılan kimyasalların tamamı Almanya devletine kayıtlı Sigma-Aldrich şirketinden ticari olarak satın alındı.

\section{LPO Aktivitesinin Ölçümü}

LPO aktivitesi, Shindler ve Bardsley'in uygulamış olduğu deneysel prosedürü üzerinde yapılan küçük değişikliklerle ölçülmüştür. Bu deney prosedürü kromojenik bir substrat olan ABTS molekülünün yükseltgenmesi sonucu oluşan yeşil renkli bileşiğin $412 \mathrm{~nm}$ 'de absorbansta yapmış olduğu artışın belirlenmesi esasına dayanmaktadır. ${ }^{14}$

\section{Protein Tayini}

Protein miktarları, negatif bir yüke sahip olan Coomassie Brillant Blue G-250 bileşiğinin pozitif yüklü protein ile kompleks yapması sonucu oluşan renkli bileşiğin 595 nm'de absorbansının ölçülmesi esasına dayanan Bradford yöntemine göre belirlendi. Sığır serum albümini standart bir protein olarak kullanarak protein miktarlarını belirlemek için standart bir grafik çizildi. ${ }^{15}$

\section{LPO’nun Saflaştırılması}

LPO, Sepharose 4B-L-tirozin-sülfanilamit afinite kolonu kullanılarak saflaștırıldı. Hazırlanan afinite kolonu fosfat tamponu (10 $\mathrm{mM}, \mathrm{pH}$ 6,8) ile dengelendikten sonra hazırlanan homojenat kolona yüklendi. Daha sonra afinite jeli fosfat tamponu $(400 \mathrm{~mL}, 25$ $\mathrm{mM}, \mathrm{pH} 6,8$ ) ile iyice yıkand. Son olarak kolona tutunmuş olan LPO enzimi $\mathrm{NaCl} / \mathrm{Na}_{2} \mathrm{HPO}_{4}$ çözeltisi (1 M/0,25 M, pH:6,8) ile elüe edildi. ${ }^{16}$

\section{SDS-PAGE (Sodyum Dodesil Sülfat- Poliakrilamid Jel Elektroforezi)}

Saflaştırılan LPO enziminin saflığını kontrol etmek için, Laemmli metoduna göre SDS-PAGE yapıldı. ${ }^{17}$

\section{In Vitro İnhibisyon Çalıșmaları}

Sesamolün inhibisyon etkisi $\left(\mathrm{IC}_{50}\right)$ LPO enzimi üzerine en az beş farklı inhibitör konsantrasyonunda çalışılarak çizilen grafikten belirlendi. IC $\mathrm{C}_{50}$ değeri belirlendikten sonra üç farklı sesamol ve beș farklı substrat konsantrasyonlarında yapilan aktivite ölçümleri sonucunda elde edilen değerlerden Lineweaver ve Burk eğrisi çizildi. Bu grafikten de sesamolün $\mathrm{K}_{\mathrm{i}}$ değeri ve inhibisyon tipi belirlendi. İnhibisyon çalışmaları en az üç tekrarlı olacak şekilde gerçekleştirildi.

\section{Araştırmanın Etik Yönü}

Sunulan bu çalışmanın bütün deneyleri; Atatürk Üniversitesi, Fen Fakültesi, Kimya Bölümü, Biyokimya Araştırma Laboratuvarında Kimya Bölüm Başkanlığı'nın 55885869-900-E.2000330244 sayılı izni ile 01/07/2020 tarihinde başlanarak tamamlanmıştır.

\section{BULGULAR VE TARTIŞMA}

Süt ve süt ürünlerinin beslenmedeki önemi ve insan sağlığına katkıları çağlardan günümüze kadar bilinmektedir. Süt, iki büyük protein ailesine sahip bir protein sisteminden oluşur. Bunlar; çözünmeyen kazein ve çözünür peynir altı suyu proteinleridir. Kazein tüm sütün \%80'ini olușturur ve izoelektrik 
çökeltme yöntemiyle yağsız sütten kolayca ayrılabilir. Peynir alt1 suyu proteinleri, bileşimlerinde asidik veya bazik ve hidrofobik veya hidrofilik amino asitler içeren alfasarmal motiflere sahip karmaşık moleküllerdir. Peynir altı suyu proteinleri; b-laktoglobulin, immünoglobulinler, a-laktalbumin, sığır laktoferrin ve laktoperoksidaz, sığır serum albümin ve küçük bileşimleri içerir. ${ }^{18}$

Biyoaktif bileşenlere sahip süt, makro ve mikro besin maddelerinin yanı sira hastalık risklerini azaltan antioksidan bileşenler de içerir. Süt ayrıca, yeni doğanın hayatta kalmasını sağlayacak temel besinleri ve yapısında doğal bir antioksidan etkiler gösteren bileşenler içerir. Laktoperoksidaz, lizozim ve laktoferrin gibi birçok süt proteini hem yeni doğanlarda hem de yetişkinlerde sağlığın korunması için önemlidir. ${ }^{19}$

Sütteki laktoperoksidaz sisteminin antibakteriyel etkisi, $\mathrm{SCN}^{-}$iyonlarının $\mathrm{H}_{2} \mathrm{O}_{2}$ varlığında katalizlenen reaksiyonu sonucu oluşan ürünlere dayanır. ${ }^{20}$ Tiyosiyanatın oksidasyonu sırasında oluşan aktif ara ürünün hipotiyosiyanat olduğu kabul edilir. Laktoperoksidaz sisteminin $\left(\mathrm{OSCN}^{-1}, \mathrm{SCN}^{-1}\right)$ ara aktif oksidasyon ürünlerinin; dış zar, hücre duvarı, sitoplazmik zar, taşıma sistemleri, glikolitik enzimler ve bazı bakteriler gibi hücre sistemleri üzerinde etkisi olduğu bilinmektedir. $^{21}$

Sesamol ile farmakolojik açıdan hem in vivo hem de in vitro olarak birçok çalıșma yapılmıştır. Antioksidan aktivitesi, lipid peroksidasyonuna etkisi, kardiyo koruyucu etkisi, merkezi sinir sistemi üzerine etkisi, antikanser aktivitesi, metabolik organlar üzerine etkisi, antienflamatuvar potansiyelin belirlenmesi ve enzim inhibisyon çalışmaları bunlardan bazılarıdır. ${ }^{22}$

Günümüzde enzimler; tıp, gıda ve çevre endüstrilerinde yaygin olarak kullanılmaktadır. İnhibitörlerin metabolik mekanizmalarının açıklanması biyokimyacılar için önemli bir çalışma alanıdır. ${ }^{23}$ Sesamolün kan-beyin bariyerini kolaylıkla geçebildiği yapılan çalışmalarda açık bir şekilde gösterilmektedir. $\mathrm{Bu}$ çalışmalar göz önüne alındığında; karaciğer başta olmak üzere, böbrekler, meme bezleri ve beyin gibi birçok doku ve hücreler sesamol tarafından etkilenebilmektedir. ${ }^{24,}{ }^{25}$ Sesamol üzerine yapılan çalışmalar incelendiği zaman enzimler üzerine inhibisyon etkilerinin belirlenmesine yönelik çok fazla çalışmanın bulunmadığını görebilmekteyiz. Bu detaydan yola çıkılarak sesamol molekülünün sığır sütünden saflaştırılan LPO üzerine inhibisyon parametreleri yapılan çalışmalar ile belirlenmiştir (Tablo 1).

Tablo 1. Sesamolün LPO Üzerine Toplu İnhibisyon Sonuçları

\begin{tabular}{cccc}
\hline Molekül & IC $_{50}(\mathbf{n M})$ & $\mathbf{K}_{\mathbf{i}}(\mathbf{n M})$ & $\begin{array}{c}\text { Inhibisyon } \\
\text { Tipi }\end{array}$ \\
\hline Sesamol & 138,629 & $80,599 \pm 3,669$ & Yarışmalı \\
\hline
\end{tabular}

Sesamolün in vitro koşullarda inhibisyon parametrelerini belirlemek için öncelikle sığır sütünden LPO enzimi saflaştırıldı. Afinite tekniğinin (ligant olarak sülfanilamit) kullanıldığı saflaştırma işleminde \%75,99 verim ve 467,51'lik bir saflaştırma katsayısı ile LPO enzimi elde edildi (Tablo 2).

Tablo 2. LPO Enziminin Saflaştırma Sonuçları

\begin{tabular}{|c|c|c|c|c|c|c|c|c|}
\hline $\begin{array}{l}\text { Saflaştırma } \\
\text { Basamakları }\end{array}$ & $\begin{array}{c}\text { Toplam } \\
\text { Hacim } \\
\text { (ml) }\end{array}$ & $\begin{array}{l}\text { Aktivite } \\
(\text { EÜ.ml-1) }\end{array}$ & $\begin{array}{l}\text { Protein } \\
\left(\mathbf{m g . m l}^{-1}\right)\end{array}$ & $\begin{array}{c}\text { Toplam } \\
\text { Protein } \\
\text { (mg) }\end{array}$ & $\begin{array}{c}\text { Toplam } \\
\text { Aktivite } \\
\text { (Eய̈) }\end{array}$ & $\begin{array}{c}\text { Spesifik } \\
\text { Aktivite } \\
\left.\text { (Ë̈.mg }{ }^{-1}\right)\end{array}$ & $\begin{array}{c}\text { Yüzde } \\
\text { Verim } \\
(\%)\end{array}$ & $\begin{array}{c}\text { Saflaştırma } \\
\text { katsayısı }\end{array}$ \\
\hline Homojenat & 50,0 & 0,973 & 9,3 & 465 & 48,65 & 0,1046 & 100 & 1 \\
\hline $\begin{array}{c}\text { Afinite } \\
\text { Kromatografisi }\end{array}$ & 7,0 & 5,282 & 0,108 & 0,756 & 36,97 & 48,902 & 75,99 & 467,51 \\
\hline
\end{tabular}


Saflaştırılan LPO enziminin saflığı yapılan SDS-PAGE ile kontrol edildi ve molekül kütlesi yaklaşık $78 \mathrm{kDa}$ olarak belirlendi (Şekil 1).

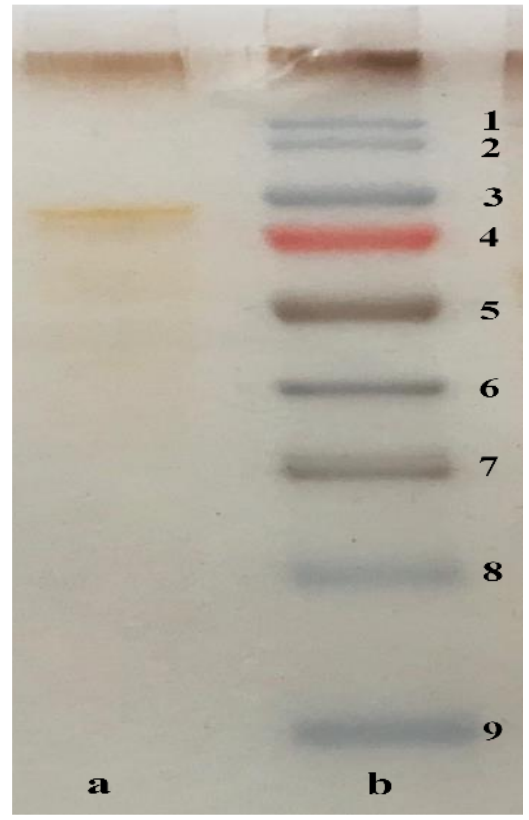

Şekil 1. SDS-PAGE Fotoğrafi.

*(A kolonu: saf LPO; B kolonu: 1: $250 \mathrm{kDa}, 2: 130 \mathrm{kDa}$, 3: $95 \mathrm{kDa}$, 4: $72 k D a, 5: 55 k D a$, 6: $36 k D a, 7: 28 k D a, 8: 17 k D a, 9: 10 k D a$ (Thermo Scientific: Cat. No. 26619)

Sesamol molekülünün 5 farklı konsantrasyonunda yapılan aktivite ölçümleri neticesinde çizilen \% aktiviteye karşı sesamol konsantrasyonu grafiğinden $\mathrm{IC}_{50}$ değeri belirlendi (Şekil 2). Enzimin aktivitesini yarıya düşüren inhibitör konsantrasyonunu ifade eden bu değer sesamol için 138,629 nM olarak hesaplandi.

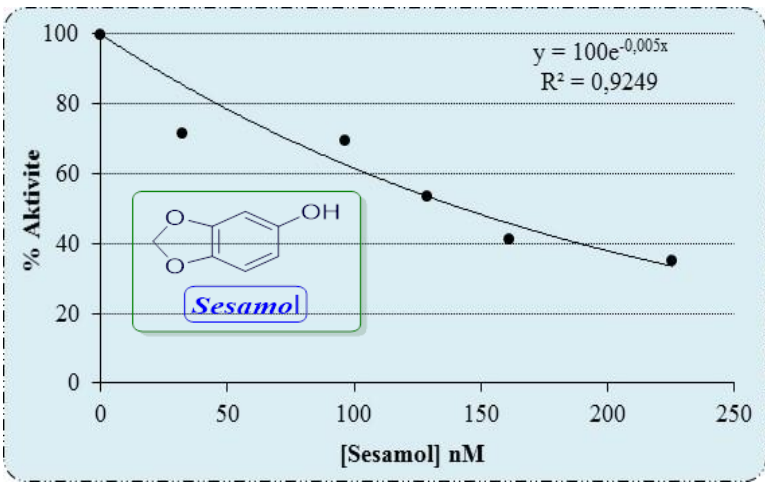

Şekil 2. Sığır Sütü LPO Enzimi İçin ABTS Substratına Bağlı Olarak Sesamol İle Elde Edilen Aktivite(\%)-[Sesamol] Grafiği

Sesamolün $\mathrm{K}_{\mathrm{i}}$ değeri ve inhibisyon tipi; 5 farklı ABTS konsantrasyonuna karşı 3 farklı sesamol konsantrasyonunda yapılan aktivite ölçümleri neticesinde çizilen Linewear-Burk grafiğinden tespit edildi (Şekil 3). Enzim ile inhibitör arasındaki kompleksin ayrışma sabitini gösteren $\mathrm{K}_{\mathrm{i}}$ değeri 80,599 $\pm 3,669 \mathrm{nM}$ olarak hesaplanırken inhibisyon tipi ise yarışmalı inhibisyon olarak belirlendi. Tespit edilen inhibisyon tipine bakıldığında molekül inhibisyon etkisini LPO enziminin aktif merkezine bağlanarak göstermektedir.

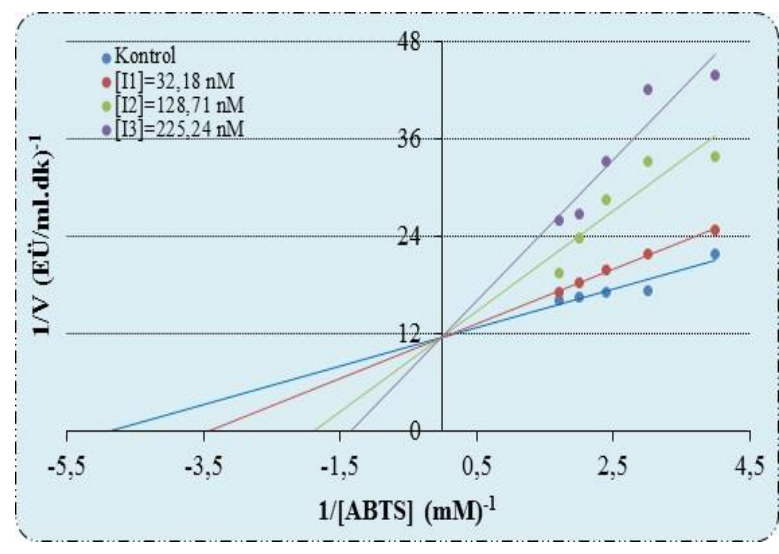

Şekil 3. Sığır Sütü LPO Enzimi İçin ABTS Substratına Bağlı Olarak Sesamolden Elde Edilen 1/V ve 1/[ABTS] Grafiği

Yapılan çalışmanın sonuçlarına göre sesamol molekülü LPO enzimini nM seviyelerde güçlü bir șekilde inhibe etmiștir. LPO için potansiyel inhibitör özelliği gösteren sesamolün düşük konsantrasyonlarda enzim aktivitesini azalttığı elde edilen sonuçlar ile belirlenmiştir.

Biyolojik olarak oldukça aktif bir bileşik olan sesamolün endikasyon profili birçok çalışmada araştırılmış ve elde edilen sonuçlara göre bu molekülün aktif olduğu kanıtlanmıștır. Farmakokinetik özellikleri oral formülasyon için iyi bir aday olabileceğini göstermektedir. ${ }^{22}$ Tüm yapılan bu çalışmalar sesamolün farmakolojik açıdan oldukça faydalı bir molekül olduğunu ispatlamıştır. Ancak, bu çalışmadan elde ettiğimiz sonuçlar gösteriyor ki sesamol, yeni doğan bebeklerin bağırsak sistemlerini ve laktasyon dönemindeki annelerin meme bezlerini patojen mikroorganizmalara karş1 koruyan laktoperoksidaz sistemini $\mathrm{nM}$ gibi çok düşük konsantrasyonlarda inhibe ederek doğal bir antimikrobiyal sisteme zarar vermektedir. 
Asetilkolinesteraz (AChE) ve $\alpha$-glikozidaz enzimler üzerine sesamolün inhibisyon etkilerini belirlemek üzere yapılan çalışmada molekülün her iki enzimi de güçlü bir şekilde inhibe ettiği belirtilmiştir. $\mathrm{Bu}$ çalışmada, AChE için $86,63 \mathrm{nM}$ ve $\alpha$-glycosidase için ise 99,00 nM'lık elde edilen IC $_{50}$ değerleri sesamolün ne kadar güçlü bir inhibitör olduğunu göstermektedir. ${ }^{26}$ Sunulmuş olan bu çalışmada elde ettiğimiz nM seviyelerdeki inhibisyon sonuçları bu çalışmaları destekler niteliktedir.
LPO üzerine moleküllerin inhibisyon kinetiklerini belirlemeye yönelik birçok çalışma bulunmaktadır. Bu çalışmalarda başta fenolik ve doğal ürünler olmak üzere, çeşitli sülfanilamit türevleri, bazı vitaminler ve hormonlar, avermektin türevleri, fenolik asitler ve bazı tiyofen bileşikleri gibi moleküllerin inhibisyon parametreleri çalışılarak literatüre sunulmuştur. ${ }^{27}$ Sunulan bu çalışma ile de sesamolün detaylı inhibisyon kinetiği literatüre kazandırılmıștır.

\section{SONUÇ VE ÖNERILLR}

Sonuç olarak, susam tohumlarından elde edilen bir bileșik olan sesamol, çeșitli hastalık ve bozuklukların tedavisi için bilim camiası tarafindan geniş çapta çalışılmış bir moleküldür. Ancak bu çalışmalarda, LPO sistemi üzerine inhibisyon etkisi araştırılmamıştır. Bu yüzden, öncelikle LPO enzimi afinite kromatografisi tekniği kullanılarak sığır sütünden izole edildi. Daha sonra ise in vitro koşullar altında sesamolün inhibisyon parametreleri detaylı bir şekilde incelendi. Elde edilen sonuçlara göre bu molekül LPO sistemini nM seviyelerde inhibe ettiği belirlendi. Süt ve mukozal sıvılarda bulunan LPO'nun, bakterileri parçalayarak uzaklaștırmak için doğuștan gelen bağıșıklık sistemi için çok hayati öneme sahip bir aktivitesi vardır. Eğer LPO sisteminde aksaklıklar ortaya çıkarsa, bu bağıșıklık sistemini ciddi anlamda etkileyebilmektedir. $\mathrm{Bu}$ durum özellikle yeni doğan bebekler için pek de istenen bir durum değildir. Bu yüzden laktasyon dönemindeki annelerin, bebeklerin bağışıklık sistemini dirençli tutmak için inhibisyonlardan kaynaklı sorunlara karşı çok dikkatli olmalılar.

KAYNAKLAR

1. Sanchez-Sanchez, ML, Garcia-Vigara, A, Hidalgo-Mora, JJ, Garcia-Perez, MA, Tarin, J, Cano, A. (2020). Mediterranean diet and health: A systematic review of epidemiological studies and intervention trials. Maturitas, 136, 25-37.

2. Albonico, F, Barelli, C, Albanese, D, Manica, M, Partel, E, Rosso, F, Ripellino, S, Pindo, M, Donati, C, Zecconi, A, Mortarino, M, Hauffe, HC. (2020). Raw milk and fecal microbiota of commercial Alpine dairy cows varies with herd, fat content and diet. Plos one, 15 (8), e0237262.

3. Mastorakou, D, Ruark, A, Weenen, H, Stahl, B, Stieger, M (2019). Sensory characteristics of human milk: Association between mothers' diet and milk for bitter taste. Journal of dairy science, 102 (2), 1116-1130.

4. Erdem, HU, Kalın, R, Özdemir, N, Özdemir, H. (2015) Purification and Biochemical Characterization of Peroxidase İsolated From White Cabbage (Brassica oleracea Var. Capitata F. Alba). International Journal of Food Properties, 18, 20992109

5. Somturk, B, Kalin, R, Özdemir, N. (2014). Purification of Peroxidase From Red Cabbage (Brassica oleracea Var. Capitata F. Rubra) by Affinity Chromatography. Applied Biochemistry and Biotechnology, 173, 1815-1828.

6. Halliwell, B. (1984). Oxygen radicals: A Commonsense Look at Their Nature and Medical Importance. Medical Biology, 62, 7177.
7. Kumar, R, Bhatla, KL. (1995). Purification, Crystallization and Preliminary X-Ray Crystallographic Analysis of Lactoperoxidase from Buffalo Milk. Acta Crystallographica, 51, 1094-1096.

8. Fonteh, FA, Grandison, AS, Lewis, MJ. (2002). Variations of Lactoperoxidase Activity and Thiocyanate Content in Cows' and Goats' Milk Throughout Lactation. Journal of Dairy Research. 69, 401-409.

9. El Agamy, EI, Ruppanner, R, Ismail, A, Champagne, CP, Assaf, R. (1992). Antibacterial and Antiviral Activity of Camel Milk Protective Proteins. Journal of Dairy Research, 59 (2), 169-175.

10. Köksal, Z, Kalın, R, Gülçin, İ, Özdemir, H, Atasever, A. (2016). The Impact of Some Avermectins on Lactoperoxidase in Bovine Milk. International Journal of Food Properties, 19 (6), 1207 1216.

11. Shyu, YS, Hwang, LS. (2002). Antioxidative Activity of the Crude Extract of Lignan Glycosides from Unroasted Burma Black Sesame Meal. Food Research International, 35, 357-365.

12. Bankole, MA, Shittu, LAJ, Ahmed, TA, Bankole, MN, Shittu, RK, Terkula, K, Ashiru, OA. (2007). Synergistic Antimicrobial Activities of Phytoestrogens in Crude Extracts of Two Sesame Species against Some Common Pathogenic Microorganisms. African Journal of Traditional, Complementary and Alternative Medicines, 4, 427-433. 
13. Alencar, JS, Pietri, S, Culcasi, M, Orneto, C, Piccerelle, P, Reynier, JP, Portugal, H, Nicolay, A, Kaloustian, J. (2009). Interactions and Antioxidant Stability of Sesamol in Dryemulsions. Journal of Thermal Analysis and Calorimetry, 98, 133-143.

14. Shindler, JS, Bardsley, W. (1975). Steady-State Kinetics of Lactoperoxidase With ABTS as Chromogens. Biochemical and Biophysical Research Communications, 67, 1307-1312.

15. Bradford, MM. (1976). A Rapid and Sensitive Method for the Quantitation of Microgram Quantities of Protein Utilizing the Principle of Protein-Dye Binding. Analytical Biochemistry, 72 (1-2), 248-251.

16. Köksal, Z, Kalın, R, Gerni, S, Gülçin, İ, Özdemir, H. (2017). The Inhibition Effects of Some Natural Products on Lactoperoxidase Purified from Bovine Milk. Journal of Biochemical and Molecular Toxicology, 31 (9), E21939.

17. Laemmli, DK. (1970). Clevage of Structual Proteins During in Assembly of the Head of Bacteriophage T4. Nature, 227, 680683.

18. Madureira, AR, Pereira, CI, Gomes, AMP, Pintado, ME, Malcata, FX. (2007). Bovine Whey Proteins - Overview on Their Main Biological Properties. Food Research International, 40, 1197-1211.

19. López-Expósito, I, Manso, MA, López-Fandiño, R, Recio, I (2008). Activity Against Listeria Monocytogenes of Human Milk During Lactation. A Preliminary Study. Journal of Dairy Research, 7 (1), 24-29.

20. Sarıkaya, SBO, Şișecioğlu, M, Çankaya, M, Gülçin, İ, Ozdemir, H. (2015). Inhibition Profile of A Series of Phenolic Acids on Bovine Lactoperoxidase Enzyme. Journal of Enzyme Inhibition and Medicinal Chemistry, 30 (3), 479-483.

21. Şişecioğlu, M, Uğuz, MT, Çankaya, M, Özdemir, H, Gülçin, İ. (2011). Effects of Ceftazidime Pentahydrate, Prednisolone, Amikacin Sulfate, Ceftriaxone Sodium and Teicoplanin on Bovine Milk Lactoperoxidase Activity. Internatıonal Journal of Pharmacology, 7, 79-83

22. Shah, A, Lobo, R, Krishnadas, N, Surubhotla, R. (2019) Sesamol and Health-A Comprehensive Review. Indian Journal of Pharmaceutical Education and Research, 53 (2), 28-42.

23. Atmaca, U, Yıldırım A, Taslimi, P, Tuncel, Çelik S, Gülçin, I, Supuran,, CT, Celik, M. (2018). Intermolecular Amination of Allylic and Benzylic Alcohols Leads to Effective Inhibitions of Acetylcholinesterase Enzyme and Carbonic Anhydrase I and II Isoenzymes. Journal of Biochemical and Molecular Toxicology, 32, e22173.

24. Jan, KC, Ho, CT, Hwang, LS. (2008). Bioavailability and Tissue Distribution of Sesamol in Rat. Journal of Agricultural and Food Chemistry, 56, 7032-7037.

25. Bayrak, C, Taslimi,, P, Kahraman, HS, Gülçin, İ, Menzek, A. (2019). The First Synthesis, Carbonic Anhydrase Inhibition and Anticholinergic Activities of Some Bromophenol Derivatives with Including Natural Products. Bioorganic Chemistry, 85, 128 139.

26. Topal, M. (2019). The Inhibition Profile of Sesamol Against AGlycosidase and Acetylcholinesterase Enzymes. International Journal of Food Properties, 22 (1), 1527-1535.

27. Özyürek, IN, Kalın, R, Özdemir, H. (2020). The Inhibition Effects of D-Penicillamine, D-Penicillamine disulfide and $\mathrm{N}$ Acetyl-D-Penicillamine on Lactoperoxidase Enzyme Activity. Journal of the Institute of Science and Technology, 10 (2), 11461153. 